\title{
Wolna elekcja króla Rzeczypospolitej Obojga Narodów
}

\section{Wprowadzenie}

Po śmierci ostatniego Jagiellona na tron Rzeczypospolitej Obojga Narodów szlachta wybierała głowę państwa viritim, co oznaczało, że każdy szlachcic miał prawo brać udział w procedurze elekcji ${ }^{1}$. Koncepcja ta wypływała z zasady równości wszystkich wobec prawa i oznaczała, że głos szlachcica waży tyle samo, co głos senatora ${ }^{2}$. W istocie jednak ta konstatacja dotyczy głównie prawa wyborczego, które obecnie w terminologii prawa ustrojowego nazywa się czynnym; mianowicie, jest to prawo przysługujące obywatelom, które zapewnia im możliwość udziału w głosowaniu i oddania głosu na swojego kandydata ${ }^{3}$. $\mathrm{W}$ polu zainteresowania badaczy elekcji viritim znajdowała się więc kwestia kręgu uprawnionych do głosowania $\mathrm{z}$ uwzględnieniem różnego rodzaju ograniczeń $^{4}$. Zagadnienie biernego prawa wyborczego nie było przedmiotem szerszych rozważań, przykładowo zostało zaledwie wspomniane w jednej z publikacji,

${ }^{1}$ W. Uruszczak: Historia państwa i prawa polskiego. T. 1: (966-1795). Warszawa 2013, s. 211.

${ }^{2}$ M. Ujma: Sejmik lubelski 1572-1696. Warszawa 2003, s. 59.

3 A. Frydrych-Depka: „Prawnoczłowiecze” spojrzenie na czynne prawo wyborcze. „Studia Wyborcze” 2016, T. 21, s. 33-34.

${ }^{4}$ Por. I. Lewandowska-Malec: Prawo do elekcji króla Rzeczypospolitej $w$ latach 1587-1648. W: Historia testis temporum, lux veritatis, vita memoriae, nuntia vetustatis: ksiega jubileuszowa dedykowana profesorowi Włodzimierzowi Kaczorowskiemu. Red. E. Kozerska, M. Maciejewski, P. Stec. Opole 2015, s. 255-269. 
stanowiącej dorobek konferencji, poświęconej wolnym elekcjom w państwie polsko-litewskim XVI-XVIII w., która odbyła się w Ustroniu w 2014 r. ${ }^{5}$. Na to pytanie nie odpowiada autor monografii o Artykułach henrykowskich, które w swoim pierwszym postanowieniu regulowały kwestię elekcji tronu.

Nadmienić wypada, że powszechnie uważa się, iż wolna elekcja oznaczała wybór króla z pominięciem zasad dynastycznych i jest zwykle utożsamiana $\mathrm{z}$ elekcją viritim? ${ }^{7}$.

Procedurę elekcyjną po 1572 r. zderza się z regulacją zawartą w Konstytucji 3 maja $1791 \mathrm{r}$. na zasadzie przeciwstawności; szlachta do momentu uchwalenia Ustawy Rządowej miała mieć zagwarantowane nieskrępowane prawo wyboru króla, natomiast pod rządami konstytucji majowej przewidziano „elekcję familii”, a więc wybór dynastii i $\mathrm{w}$ jej ramach sukcesję de lumbis na zasadach primogenitury; wyjątkowo Konstytucja z 1791 r. przewidziała dziedziczenie tronu po Fryderyku Auguście III Wettynie przez jego jedyną córkę Marię Augustę Nepomucenę, przenosząc prawa do tronu dziedzicznego w Rzeczypospolitej na ród jej męża ${ }^{8}$. Warto $\mathrm{w}$ tym miejscu odnieść się do wcześniejszego okresu panowania Jagiellonów. K. Śmigiel przyjął, że „W okresie panowania Jagiellonów tron polski dziedziczyła dynastia, natomiast elekcja dotyczyła osoby kandydata na króla"9. Fakty dowodzą, że zasady takie były respektowane, choć nie zostały jasno wyrażone w ówczesnym prawie. Problem, który występował w dziejach Rzeczypospolitej, to brak zdefiniowania pojęcia elekcji; czy oznaczała wybór dowolnego kandydata, czy była ona związana jedynie z prawem swobodnego obioru, jednak w obrębie dotychczas panującego rodu, w szczególności jeśli żyli potomkowie poprzedniego władcy.

Przedmiotem niniejszego opracowania jest kwestia poprawności dotychczasowych ustaleń dotyczących kręgu uprawnionych do kandydowania na tron Rzeczypospolitej polsko-litewskiej w okresie od 1572 do $1791 \mathrm{r}$.

${ }^{5}$ Wokót wolnych elekcji w państwie polsko-litewskim XVI-XVIII wieku. O znaczeniu idei wyboru - między prawami a obowiązami. Red. M. Markiewicz, D. Rolnik, F. Wolański. Katowice 2016.

${ }^{6}$ D. Makiłła: Artykuly henrykowskie (1573-1576). Geneza - obowiazywanie - stosowanie. Studium historyczno-prawne. Warszawa 2012.

${ }^{7}$ Wolna elekcja — „wybór monarchy nieprzestrzegający zasad sukcesji dynastycznej. W Rzeczypospolitej Obojga Narodów przybyła na pole elekcyjne w trybie pospolitego ruszenia, szlachta głosowała województwami w obecności posłów, którzy zanosili jej głosy do Senatu: wybór króla ogłaszał marszałek, mianował natomiast prymas Polski. Senatorowie wiedli wiodącą rolę w ustalaniu ostatecznych wyników wolnej elekcji, https://pl.wikipedia.org/ wiki/Wolna_elekcja [dostęp: 14.02.2018]; http://www.tomaszewska.com.pl/elekcja.pdf [dostęp: 6.05.2019].

${ }^{8}$ Volumina Legum. T. 9. Kraków 1889, s. 223.

9 K. Śmigiel: Prymasi interreksi. „Studia Gnesnensia” 2011, T. 25, s. 347. 


\section{Pojęcie wolnej elekcji}

Pojęcia wolnej elekcji nie wyjaśniono dotychczas dostatecznie w literaturze przedmiotu. J. Dzięgielewski, przytaczając postanowienia przywileju wydanego przez Zygmunta Augusta na sejmie w 1538 r., wspomniał jedynie za tekstem aktu, że elekcja powinna być wolna ${ }^{10}$. We wstępie do opracowania pod redakcją A. Ziober wolna elekcja jest utożsamiana $\mathrm{z}$ elekcją viritim ${ }^{11}$. D. Makiłła dostrzega w pojęciu wolnej elekcji dwa aspekty: zasadę powszechności udziału w elekcji oraz zakaz dziedziczenia tronu ${ }^{12}$.

Jednym z warunków osiągnięcia celu, aby elekcja była wolna, było unikanie wszelkiego gwałtu na polu elekcyjnym, aby wybór był nieskrępowany żadnym naciskiem czy przymusem. Szczególnie obawiano się tak zwanych „praktyk”, czyli intryg politycznych, fakcji, manipulacji wyborczych, „bo kto przez moc i praktykę bywa obierany, ten też przez moc i praktykę zwykł panować"13. W tym celu sejm w 1573 r. uchwalił porządek, którym mieli kierować się obecni na elekcji, „aby żaden na te place, gdzie się województwa do namiotów swych zjeżdżają i tam gdzie się ich mość panowie rada i z rycerstwem wszystkim do rady zjeżdżają, z żadną zbroją, z żadną strzelbą ani ze wszelaką bronią, okrom zwyczajnej [...] przyjachać ważyć się nie śmiał"14. Z kolei w akcie konfederacji generalnej warszawskiej z 7 marca 1587 r. nakazano: ,żadnego rozerwania między sobą ani dismembracyi żadnej nie czynić ani dopuścić, iako w iednej a nierozdzielnej Rzeczypospolitej, ani iedna część bez drugiej pana sobie obierać i factione privata narabiać, abo kogo przez praktykę ku ubliżeniu wolnej elekcji wsadzać na Królestwo, biorąc dary abo pieniądze, tak ku swemu pożytkowi iako i ku zbieraniu ludzi, abo też obietnice na iakie racyje abo na authoryzacyje pana przyszłego"15.

W słowniku języka polskiego słowo ,wolny” oznacza: niezależny, samodzielny; realizuje się, gdy człowiek postępuje zgodnie z własną wolą ${ }^{16}$. Podobnym określeniem w okresie staropolskim było „wolne, nie pozwalam”, odnoszące się do liberum veto. Rodzi się przekonanie, że pojęcia te (wolnej elekcji i liberum veto) odnoszono do sfery wolności nie praw. Jak słusznie zauważa Marek Piechowiak, „nie mamy do czynienia jedynie z różnicą ję-

10 J. Dzięgielewski: Sejmy elekcyjne, elektorzy, elekcje 1573-1674. Pułtusk 2003, s. 29.

${ }_{11}$ Wolna elekcja $w$ dawnej Rzeczypospolitej. Procedura - przebieg - publicystyka. Red.

A. Ziober. Wrocław 2014, s. 5.

12 D. Makiłła: Artykuty henrykowskie..., s. 122.

${ }_{13}$ Dyjaryjusze sejmowe 1587. Sejmy konwokacyjny i elekcyjny. Wyd. A. Sokołowski. Kraków 1887, Scriptores Rerum Polonicarum, T. 21, s. 85.

${ }^{14}$ Volumina Constitutionum. T. 2: 1550-1609, Vol. 1: 1550-1585. Do druku przygotowali

S. Grodziski, I. Dwornicka, W. Uruszczak. Warszawa 2005 [dalej: VC II, 1], s. 310.

${ }_{15}$ Volumina Constitutionum. T. 2: 1550-1609, Vol. 2: 1587-1609. Do druku przygotował

S. Grodziski, przedmowa W. Uruszczak. Warszawa 2008 [dalej: VC II, 2], s. 18-19.

${ }^{16} \mathrm{https} / / / \mathrm{sjp} \cdot \mathrm{pl} /$ wolny [dostęp: 14.02.2019]. 
zyka, ale z różnicą treści ${ }^{17}$. Badacz dochodzi do wniosku, że „W przypadku praw, należny stan rzeczy jest niezależny od woli podmiotu prawa, natomiast w przypadku wolności stan ten jest współkonstytuowany wolnymi wyborami i właśnie jako taki podlega ochronie" ${ }^{18}$. Sytuacja w przypadku staropolskich elekcji monarchy nie była całkowicie jasna, skoro szlachta lubelska w trakcie bezkrólewia w 1587 r., a sieradzka i łęczycka z kolei w 1632 r. opowiadała się za przymusowym udziałem „braci” w procedurze wyborczej, strasząc karami w prawie opisanymi ${ }^{19}$. Powodem mogła być koncepcja łącząca elekcję viritim z obowiązkiem obrony kraju. Z kolei w trakcie interregnum po śmierci Michała Korybuta lublinianie opowiedzieli się za dobrowolnością udziału w elekcji ${ }^{20}$. Szlachta danej ziemi czy powiatu mogła wyrazić dobrowolnie zgodę na reprezentację przez posłów; $\mathrm{w}$ takim przypadku wyraźnie widoczny był element woli co do sposobu korzystania z możliwości udziału w wyborze króla, dzięki czemu electio Regis była libera ${ }^{21}$. Bardziej więc mamy do czynienia z wolnością elekcji niż prawem do elekcji monarchy, a tym bardziej z obowiązkiem udziału obwarowanym sankcją w razie nieprzybycia. Libera electio należała do sfery libertates, podobnie jak libertas sentiendi czy wreszcie liberum veto; były to wolności, zwane nawet źrenicami wolności, czyli swobód szlacheckich (obywatelskich). Tak też to rozumiano w owym czasie, skoro autor broszury politycznej z 1587 r. pisał: ,aby w elekcji wolny każdy szlachcic, któryby jedno chciał, w dobrym rządzie particeps tym sposobem był"22. Wyborca szlachecki nie mógł być w żaden sposób przymuszany do udziału w elekcji, decyzja w tym względzie należała do szlachcica; w takim znaczeniu rozumiano wolność elekcji ${ }^{23}$.

Wolność elekcji wiązano także ściśle z wolnością głosu; można rzec, że wolna elekcja była skutkiem stosowania libertas sentiendi, bo wolny głos rozumiano także jako prawo oddania głosu, opowiedzenia się za kandydatem przez siebie wytypowanym. Ta relacja między dwiema ,źrenicami wolności” pobrzmiewała w głosach szlacheckich po reakcjach na czytany w kole list starosty oświęcimskiego Krzysztofa Komorowskiego: „gdy czytano list pana oświęcimskiego, P. Komorowskiego, w którym zdanie swe względem elekcyi oznajmował, iż na Arcyksiażęcia Maxymiliana pozwalał, rzekł jeden z rycerstwa: znać, że niedale-

${ }^{17}$ M. Piechowiak: Prawo a wolność. W: Prawa człowieka - prawa rodziny. 30 lat Poznańskiego Zakładu Instytutu Nauk Prawnych PAN. Red. R. Hliwa, A.N. Schulz. Poznań 2003, s. 37.

${ }^{18}$ Ibidem, s. 50.

${ }^{19}$ M. Ujma: Sejmik lubelski..., s. 61, 64.

${ }^{20}$ Ibidem, s. 66.

${ }^{21}$ Por. 1538, Volumina Constitutionum. T. 1: 1493-1549, Vol. 2: 1527-1549. Do druku przygotowali W. Uruszczak, S. Grodziski, I. Dwornicka. Warszawa 2000, s. 163.

${ }^{22}$ Senator Anonim: Traktat de interregno z r. 1587. W: Sześć broszur politycznych z XVI i początku XVII stulecia. Wyd. B. Ulanowski. Kraków 1921, s. 196.

${ }^{23}$, ,...] ludzie szlacheccy do elekcyi należący, nie mają być przymuszani, aby na elekcyi byli”, ibidem, s. 199. 
ko cesarskiej ziemie mieszka. To sobie wzięli za krzywdę, powiedając: jakaż to wolna elekcya? Azaż nie miał być wolny głos każdemu na kogo się podoba?"24.

Wolną elekcję przeciwstawiano w całym omawianym okresie elekcji vivente rege, której groźba stale wisiała nad Rzecząpospolitą, bowiem kolejni królowie elekcyjni ponawiali działania zmierzające do wyboru następcy za życia władcy względnie mniej lub bardziej dyplomatycznie popierali swoje potomstwo. Pamiętano dobrze zawirowania polityczne związane z elekcją królewicza Zygmunta Augusta za życia jego królewskiego ojca. Takie starania czynił też Zygmunt III Waza, Jan Kazimierz, Jan III Sobieski czy wreszcie August II Mocny. Rozumiano wówczas, że jeśli dojdzie, jak za czasów Zygmunta Starego, do elekcji vivente rege, to elekcja po śmierci władcy, potwierdzająca prawo do tronu beneficjariusza wyboru za życia poprzednika już nie będzie nieskrępowana, lecz wymuszona. Taka elekcja nie będzie więc „wolna”. Na tej kwestii skupiał się opór braci szlacheckiej, która w elekcji vivente rege widziała największe zagrożenie dla podstaw ustroju Rzeczypospolitej prowadzące wprost do wprowadzenia zasady dziedziczności tronu ${ }^{25}$.

Rozważyć należy ponadto, czy wolność elekcji oznaczała możliwość zgłaszania się kandydatów niepowiązanych więzami dynastycznymi z poprzednikiem na tronie oraz czy w razie wielości kandydatów wybór był nieskrępowany.

\section{Bierne prawo wyborcze}

Dwaj ostatni Jagiellonowie na tronie polskim zagwarantowali, że władcy Królestwa będą wybierani, jednak do śmierci Zygmunta II Augusta nie określono szczegółowo procedury elekcji. Symptomatyczne jest jednak to, co w dniu 10 kwietnia $1573 \mathrm{r}$. wypowiedział w swojej mowie do zgromadzonej szlachty biskup Walencji, poseł kandydata do tronu - Jan Montluc: ,przodkowie wasi mogli zawsze od sukcessyi krew panów swoich odsądzać, wszakoż ich nigdy od tego nie odrażali, ale na miejsce ojców ich jakoby własnymi dziedzicami byli chętliwie sadzali; która rzecz w całości wasze swobody zachowała, bo królowie panowie wasi chociażby byli, jako wstępnymi chcieli być, musiało ich to zawsze hamować i przy skromności a sprawiedliwości zatrzymywać, aby potomstwu swemu nie zaszkodzili, widząc taką swobodę koronną, dlatego nie tylko ujmy żadnej swobody Waszmościów nie czynili, ale je i owszem rozmnażali i nadawali; zatem ta swoboda, ta wolność, ta sława przy Waszmościach jako dziedzictwem zostawa"26.

${ }^{24}$ Dyjaryjusze sejmowe 1587..., s. 205.

25 A. Szabelski: Projekty elekcji vivente rege $w$ Rzeczypospolitej, a wegierskie doświadczenia z elekcja vivente rege. W: Wolna elekcja w dawnej..., s. 96.

${ }^{26}$ Zbiór pamiętników do dziejów polskich. T. 3. Wyd. W.S. de Plater-Broel. Warszawa 1858 , s. $116-117$. 
Na sejmie elekcyjnym Henryka Walezego w maju 1573 r. stany wypracowały tekst aktu o randze zasadniczej, a mianowicie tak zwanych Artykułów henrykowskich. Faktycznie zaczęły one obowiązywać dopiero od 1576 r., gdy kolejny władca - Stefan Batory, dokonał ich zatwierdzenia. Jak stwierdził badacz Artykułów henrykowskich Dariusz Makiłła, tekst przyjęty przez księcia Siedmiogrodu ,z nieznacznymi różnicami redakcyjnymi, nie naruszającymi jednakowoż treści oraz ich znaczenia, był w zasadzie identyczny z tekstem Artykułów zatwierdzonych przez króla Henryka w Paryżu. W obu przypadkach do zatwierdzenia i przysięgi elekta dołączono tekst polski, pochodzący z thumaczenia tekstu łacińskiego, jaki został spisany w trakcie elekcji, a następnie wpisany do ksiąg grodzkich warszawskich" ${ }^{27}$. W ten sposób akt z 1573 r., będący do czasu jego zatwierdzenia przez trzeci „stan sejmujący” bardziej projektem lub aktem prawnym o mocy zawieszonej, stał się ustawą sejmową, zaprzysięganą przez kolejnych władców tak jak całe obowiązujące prawo w Rzeczypospolitejej.

Tekst łaciński w odniesieniu do interesującego nas punktu pierwszego zawierał następujące sformułowania: „Nos et successores nostri reges Poloniae”, "neque titulo haeredis, regibus Poloniae antehac solito nos aut successores nostri posthac utemur", ,post decessum nostrum et successorum nostrorum”. Elekt gwarantował: „non debemus nominare, eligere aut electionem indicere, vel quemcunque alium modum tentare instituendi et designandi domini sive regis successoris nostri" ${ }^{29}$. Czterokrotnie użyto słów successores nostri. Określenie to można tłumaczyć jako: spadkobiercy, następcy (prawni) nasi. Czy zatem chodziło o jakichkolwiek kolejnych władców czy dziedziców zmarłego króla jego potomków? Fragmentom łacińskim odpowiadało następujące tłumaczenie w języku polskim: „my i potomkowie nasi, królowie polscy”, „tytułu dziedzica używać nie mamy ani potomkowie nasi, królowie polscy”, „po zejściu naszym i potomków naszych” wreszcie: „nie mamy mianować ani obierać jakiego, składać żadnym sposobem ani kształtem wymyślonym króla, na państwo sukcesora naszego sadzać" ${ }^{30}$. Trzykrotnie jest wprost mowa o potomkach króla, a raz użyto ogólnego sformułowania „sukcesor”, co może oznaczać jakiegokolwiek kolejnego władcę. Cały tekst postanowienia punktu pierwszego Artykułów henrykowskich, zarówno w wersji łacińskiej, jak i polskiej skłania do stwierdzenia, że autorom chodziło o potomstwo (zapewne męskie) wybranego władcy ${ }^{31}$. Przekład tekstu łacińskiego na język polski został dokonany wówczas równolegle. „Potomkowie" oznaczają zstępnych w linii prostej. Wyraźnie podkreślono, że nawet po

${ }^{27}$ D. Makiłła: Artykuty henrykowskie..., s. 73.

${ }^{28}$ Por. ibidem, s. 56, 78, 80, 82-83, 108.

${ }^{29}$ Articuli conventus Electionis Generalis Regni. AGAD, Acta terrestria et castriensia Varsoviensia, t. 87, k. $17 \mathrm{v}$, za: ibidem, s. 121.

${ }^{30}$ Ibidem, s. 121-122, przyp. 275.

${ }^{31} \mathrm{~W}$ wielu innych postanowieniach określenie „My i potomkowie nasi Królowie Polscy” również było używane, por. pkt. 3, 4, 6, 7, 8, 10, 12, 16, 18, VC II, 1, s. 326-329. 
najdłuższym panowaniu obecnego króla i jego potomków ma nadal obowiązywać zasada elekcyjności tronu, a więc, nie mogąc używać tytułu dziedzica, nie osiągną wprowadzenia zasady dziedziczności korony. W tym celu użyto liczby mnogiej. Oznacza to również, że gwarantowano realnie elekcyjnemu monarsze wybór jego potomka na tron polski. Nie byłoby w tym nic dziwnego, wręcz jest to racjonalne, że wybrany król chciał zapewnić tron swojemu potomkowi. Różnica polegała na tym, że tytułem do objęcia korony była elekcja nie zaś dziedziczenie. Wybór jednak był ograniczony do potomstwa monarchy, a więc zstępnych pierwszego stopnia. Stany obradujące na sejmie elekcyjnym w $1573 \mathrm{r}$. postępowały rozważnie; w realiach II połowy XVI w. było logiczne, że nieograniczone bierne prawo wyborcze nie byłoby realistyczne. Analiza pierwszego postanowienia Artykułów henrykowskich skłania do interpretacji, że szlachta zebrana w Kamieniu dokonała, po pierwsze, wyboru dynastii, skoro mowa jest o tym, że ani Henryk Walezy ani jego potomkowie królowie polscy nie podejmą starań, aby osadzić na tronie swojego kandydata. Niejasność sformułowań utrudnia prawidłową wykładnię, lecz można przyjąć, że Walezjuszowi szlachta zagwarantowała elekcję kolejnego z grona jego potomków. Miałaby to być zatem elekcja ograniczona obligatoryjnie do członków dynastii panującej. Uwzględnienie określonej kandydatury elekta/elektów miało mieć źródło nie w decyzji panującego, lecz szlachty w najszerszym jej rozumieniu i nie w trakcie regnum, lecz interregnum. W istocie za taką interpretacją przemawia fakt, że tak właśnie postępowała szlachta w przypadku kolejnych bezkrólewi, a nadto należy skonstatować, że stosowne postanowienie Konstytucji 3 maja w tym kontekście nie jawi się jako jakieś szczególne novum. Różnica polegała na tym, że w naszej uznawanej za pierwszą ustawie zasadniczej poza elekcją dynastii wskazano zasadę primogenitury, natomiast w świetle punktu pierwszego Artykułów henrykowskich wolny wybór sprowadzał się do swobodnego wyłonienia jednego z potomków zmarłego monarchy. Należy ten przepis również tak zinterpretować, że w wypadku, gdy poprzednik zostawił jednego potomka, zostałby królem, jednak jako wybrany w drodze elekcji. Wolna elekcja w rozumieniu Artykułów henrykowskich była elekcją dynastii w połączeniu z zasadą pierwszeństwa do tronu potomstwa panującego przedstawiciela tej dynastii. Nowością było wszakże dopuszczenie do aktu wyborczego całej szlachty ${ }^{32}$. Nowatorskie było zatem podejście do czynnego prawa wyborczego, w zakresie biernego prawa nie było widocznych zmian w stosunku do okresu jagiellońskiego.

Zdaje się jednak, że inaczej powyższą normę rozumiała szlachta, skoro autor anonimowej broszury politycznej z $1587 \mathrm{r}$. pisał tak: „Acz zwykli zawżdy Polacy potomka Pana swego zmarłego brać sobie za pana ale nie inaczy, jedno tak, jeźli się im podoba, a zwłaszcza jeźli ociec jego dobrą sprawę w sobie miał, porządnie, sprawiedliwie i sławnie panował, żeby też takiejże sprawy w synie

32 D. Makiłła: Artykuty henrykowskie..., s. 136. 
jaka w ojcu beła, pewni beli" ${ }^{33}$. Środowisko szlacheckie komentowany przepis interpretowało, traktując elekcję potomka jako sytuację hipotetyczną, a więc przy założeniu, że jeśli hipotetycznie zostanie wybrany na króla potomek zmarłego monarchy, to nie będzie mógł dążyć do dziedziczności tronu. Byłaby to zatem tylko ekspektatywa prawa, nadzieja, widoki na przyszłość. Wybór potomka zmarłego króla byłby więc fakultatywny. $Z$ powyższych rozważań wynika, że wykładnia przepisu była różnoraka, bowiem szlachta czyniła starania, by poszerzyć zakres swoich wolności.

Określenie libera electio brzmiało jednak na tyle niepokojąco, że Zygmunt III jak mógł tak przedłużał chwilę potwierdzenia tej regulacji stosownym dyplomem, licząc na jak najkorzystniejszą dla jego rodu analizę prawną tego słynnego przepisu. W 1593 r. pierwszy Waza potwierdził wolność elekcji, w szczególności odżegnując się od próby scedowania korony na wybranego przez siebie kandydata $^{34}$. W związku z kolejnymi podejrzeniami o próbę cesji tronu polskiego względnie elekcji vivente rege królewicza Władysława Zygmunt III zgodził się na przyjęcie konstytucji na sejmie w 1607 r., akceptując ponownie zasadę wolnej elekcji; uchwała wyjaśniała to pojęcie: ,żaden król Polski per cessionem iuris ani przez żadne, insze ludzkim dowcipem wymyślone sposoby, Króla podawać i forytować na Królestwo i żadnym pretextem zaciągać nie ma ani będzie mógł. Ale ilekroć by Pana w Polszcze nie stało, ma to zawsze zostawać przy wolnych i zgodnych głosiech wszystkich stanów koronnych i Wielkiego Księstwa Litewskiego, narodu szlacheckiego"35. Z przytoczonego tekstu wynika zakaz obsady tronu polskiego $\mathrm{w}$ drodze jakichkolwiek umów inter vivos względnie zakulisowych machinacji przez aktualnie panującego monarchę, a w wypadku wakowania tronu wybór kolejnego władcy przez szlachtę ma mieć charakter swobodny, bez nacisku i jakiegokolwiek przymusu. Czynne prawo wyborcze szlachty zostało więc ponownie zagwarantowane. Uchwała z 1607 r. odwoływała się również do wcześniejszych praw dotyczących elekcyjności tronu, począwszy od czasów Ludwika Węgierskiego; w okresie panowania tej dynastii obowiązywały $\mathrm{w}$ istocie te same zasady, co ujawnione $\mathrm{w}$ omawianym postanowieniu Artykułów henrykowskich ${ }^{36}$. Należy zatem stwierdzić, że powyższa uchwała odnosiła się głównie do kwestii czynnego a nie biernego prawa wyborczego.

Ponownie sprawa gwarancji prawa wyboru powróciła pod obrady na kolejnym sejmie, owocując konstytucją, którą król zobowiązywał się do oblaty przywileju o wolnej elekcji ${ }^{37}$. Ostatecznie uczynił to przed śmiercią na sejmie w 1631 r., wydając dyplom, stanowiący opublikowany załącznik do konstytucji

\footnotetext{
33 Senator Anonim: Traktat..., s. 179-180.

34 1593, pkt. 3, Wolność elekcyi, VC II, 2, s. 196-197.

35 1607, pkt. 1, Najpierwej warunek wolnej elekcyi taki czyniemy, VC II, 2, s. 338.

${ }^{36}$ Por. D. Makiłła: Artykuty henrykowskie..., s. 126-131.

37 1609, pkt. 6, O warunku wolnej elekcyi, VC II, 2, s. 380.
} 
o „Warunku wolney Elekcyi”" ${ }^{38}$. Zawarto w nim zakaz obsady tronu „vel sangvinis vel successionis beneficio, vel alicujus pactionis, aut juris transfusionis praetextu, aut ullo quaesito colore". Nadal jednak obowiązywało postanowienie Artykułów henrykowskich, które wskazywało na prawa potomków zmarłego władcy do obsady tronu. W trakcie bezkrólewia w 1632 r. szlachta nie miała wątpliwości, aby wybrać Wazę i to najstarszego spośród synów Zygmunta III, pomimo starań jego drugiej żony ukierunkowanych na osobę Jana Kazimierza. Regulacja Henrykowa została zatem zrealizowana. Jednak kwestię elekcji postanowiono wówczas zawrzeć w paktach konwentach Władysława IV, podobnie jak kilka innych przejątków z Artykułów henrykowskich. Pytanie, po co dokonywano tego zabiegu? Dariusz Makiłła jest zdania, że była to nowelizacja odnośnych postanowień ${ }^{39}$. Jest to interpretacja wątpliwa, gdyż Artykuły henrykowskie były aktem ,prawa wiecznego" ${ }^{40}$, natomiast umowa publicznoprawna elekta ze szlachtą (pacta conventa) była dokumentem czasowym; różniła je również ranga.

W 1632 r. sytuacja była wszakże inna. Decyzje spoczywały w rękach szlachty. Pytanie, czy sejm elekcyjny mógł znowelizować pierwszy punkt Artykułów henrykowskich w interesie elektorów, by uczynić elekcję aktem wyborczym nieskrępowanym żadnymi ograniczeniami? Tych gwarancji nie dawał przepis w dotychczasowym brzmieniu. Stało się jednak inaczej; za życia Zygmunta III nie uchwalono ani procedury elekcji, ani nie zmieniono punktu pierwszego Artykułów henrykowskich. W paktach konwentach zobowiązano elekta do przyjęcia, że wolna elekcja będzie zastosowana wobec „,następujących po Nas Królów Polskich”, mowa jest też o „następcach naszych Królach Polskich”"41. Następca zaś nie oznacza wcale spadkobiercy zmarłego króla. Postanowienie to powtórzono w paktach konwentach kolejnego Wazy - Jana Kazimierza ${ }^{42}$. Co ważne, wykreślono sformułowanie ,po zejściu naszym i potomków naszych", pozostawiając jedynie jego początek, dotyczący śmierci króla — strony paktów. Ten zabieg służył umocnieniu gwarancji, że król za swojego życia nie poczyni żadnych starań $\mathrm{w}$ celu osadzenia na tronie swego potomka. Jednak pakta wygasały z chwilą śmierci władcy. Czy obowiązywały w jakiś sposób nadal? Władysław IV gwarantował stanom koronnym (senatorom i rycerstwu), że zasada elekcyjności tronu jest „prawem wiecznym”. To powtórzył również Jan Kazimierz. Reguła elekcji tronu w zmienionej formie miała zatem mieć moc trwalszą niż same pakta konwenta. Reasumując, dzięki temu zabiegowi

38 Volumina Legum. T. 3. Wyd. J. Ohryzko. Petersburg 1859 [dalej: VL III], s. 318.
39 D. Makiłła: Artykuty henrykowskie..., s. 487.
${ }^{40}$ VC II, 1, s. 326.
${ }^{41}$ VL III, s. 362.
${ }^{42}$ Volumina Constitutionum. T. 4: $1641-1668$, Vol. 1: 1641-1658. Do druku przygotowali S. Grodziski, M. Kwiecień, K. Fokt, przedmowa W. Uruszczak. Warszawa 2015 [dalej: VC IV, 1], s. 159. 
określenie libera electio zaczęto odnosić się nie tylko do kwestii czynnego, ale i biernego prawa wyborczego.

Szlachta niezmiennie pozostawała w obawie o realizację jednej ze swych „źrenic” wolności, a mianowicie wolnej elekcji. Na sejmiku halickim przed sejmem abdykacyjnym Jana Kazimierza w 1648 r. podkreślono, że wybór synów Zygmunta III sprzyjał utrwaleniu zasady dziedziczności tronu. Szlachta chciała tym samym zakomunikować, że gotowa była dla rodu Wazów wystawić Rzeczpospolitą na takie wyzwanie: ,nie tęskniło ś. P. najjaśniejszego Zygmunta Trzeciego ojca J. Kr. Mci czterdziestoszóstne panowanie meruerat ut posteri regnarent, kiedy nie obejrzawszy się na żadne potężnych kandydatów konkurencie dwóch najjaśniejszych po sobie następujących obraliśmy synów i ledwie electivam regnum nie obróciliśmy in successivam”»33.

\section{Królowie „rodacy” i elekcje saskie w Rzeczypospolitej}

Jak pisze w ogólnodostępnym tekście Zbigniew Chmiel: „Abdykacja króla Jana Kazimierza Wazy w 1668 roku postawiła przed szlachtą konieczność wyboru nowego władcy i to jeszcze za życia poprzednika, co było sprzeczne $\mathrm{z}$ dotychczasową tradycją. Wstrząs był tym większy, że na Janie Kazimierzu kończyła się dynastia, która, pomimo zasady wolnej elekcji, w osobach trzech kolejnych władców przez 81 lat dzierżyła królewską koronę" ${ }^{4}$.

Niezależnie więc od podejmowanych prób osłabienia wagi pierwszego postanowienia Artykułów henrykowskich w istocie kierowano się nim przy wyborach kolejnego władcy po śmierci jego poprzednika; zostawał nim jego potomek. Po Zygmuncie III panowali dwaj jego synowie: Władysław i Jan Kazimierz, z tym że zapewne gdyby syn Władysława - Zygmunt Kazimierz — dożył lat sprawnych $\mathrm{w}$ dacie śmierci królewskiego ojca, to byłby wybrany na króla. Sytuacja uległa diametralnej zmianie, nie tylko z powodu abdykacji Jana Kazimierza, a głównie dlatego, że nie doczekał się on legalnego potomstwa. Szlachta przystąpiła więc do elekcji monarchy z innego rodu. W 1669 r. zgłosiło się kilku kandydatów.

W kolejnej elekcji nie było niczego nadzwyczajnego, z jednym wszakże wyjątkiem: został wybrany królem „Piast” — szlachcic, co dotychczas, ze względu

${ }^{43}$ Halicz 29.07.1668, Akta grodzkie i ziemskie. T. 24: Lauda sejmikowe halickie 15751695. Wyd. A. Prochaska. Lwów 1931, s. 271.

${ }^{44}$ http://www.wilanow-palac.pl/elekcja_michala_korybuta_wisniowieckiego.html [dostęp: 19.02.2019]. 
na obawę złamania zasady równości, nie było dopuszczalne. Drogę do tego utarły na pewno elekcje synów Zygmunta III, których nie uważano za obcych, choć z pewnością legitymowali się królewskim pochodzeniem, którym nie mógł się pochwalić król elekt z 1669 r. Michał Korybut Wiśniowiecki, syn słynnego księcia Jaremy, krótko pozostał na tronie, gdyż po czterech latach panowania zmarł niespodziewanie w 1673 r. w trakcie pożogi tureckiej nad Rzecząpospolitą To utorowało drogę do korony hetmanowi Janowi Sobieskiemu, zwycięzcy spod Chocimia, również kandydatowi rodzimemu i szlacheckiemu. Michał Korybut nie pozostawił potomstwa, nie było zatem potrzeby rozważać problemu uprawnień ewentualnych sukcesorów do pierwszeństwa w akcie elekcji. Inna sytuacja nastąpiła z chwilą śmierci Jana III, który pozostawił po sobie kilku synów, z których Jakub był najpoważniejszym kandydatem. Na przeszkodzie stało jednak to, że wobec Jakuba Sobieskiego jeszcze w 1674 r. wysuwano zarzuty, że nie miał statusu królewicza, jako że przyszedł na świat, gdy jego ojciec jeszcze nie uzyskał korony ${ }^{45}$. Miał jednak pewne szanse na tron, ale konflikt w łonie rodziny, szczególnie z matką Marią Kazimierą ${ }^{46}$, skutecznie pozbawił go tych nadziei ${ }^{47}$. Sednem sporu były sprawy majątkowe, bowiem dorosły Jakub chciał objąć w spadku majątek ojcowski, natomiast królowa Marysieńska rościła sobie pretensje do dożywocia na nim; dotychczasowe konstytucje, w tym te z 1631 r., odnoszące się do kwestii majątkowych królewskiej wdowy były wielce niejasne ${ }^{48}$.

Konwokacja w trakcie bezkrólewia, choć „niedoszła” i „rozerwana”, jednak zdecydowała o terminie elekcji, wyznaczając ją na dzień 15 maja 1697 r. ${ }^{49}$. Królem mógł zostać tylko katolik, tego wyznania musiała być również królowa. W podjętej uchwale wyłączono możliwość kandydowania „Piasta”, czyli przedstawicieli rodzimych rodów magnackich, choć podkreślono ich wielkość i zasługi. Stany Rzeczypospolitej obawiały się jednak niezgody oraz wzajemnych, fakcyjnych konfliktów, wreszcie uznawały osobę króla — „Piasta” za obniżającą pozycję państwa na arenie międzynarodowej ${ }^{50}$. Zabezpieczenie elekcji wolnej od wszelkiej korupcji i praktyk uznano za sprawę najważniejszą, poświęcając jej wiele miejsca ${ }^{51}$. Na nic się to zdało, gdyż wybór następcy Jana III odbył się w gorszącym nieładzie, kłótniach i niezgodzie. Wyraz temu daje sam tekst

${ }^{4}$ J. Woliński: Epilog elekcji 1674 r. Kraków 1952, s. 7, 11, 31. i nast.

${ }^{46}$ E. Gąsior: Sejm konwokacyjny po śmierci Jana III Sobieskiego. Warszawa 2017, s. 47

${ }^{47}$ Por. K. Jarochowski: Dzieje panowania Augusta II od śmierci Jana III do chwili wstapienia Karola XII na ziemie polska. Poznań 1856, s. 6-8.

${ }^{48}$ Ibidem, s. 12-13.

49 Volumina Legum. T. 5. Wyd. J. Ohryzko. Petersburg 1860 [dalej: VL V], s. 408—412.

${ }^{50}$ G. Glabisz: Sejmik województwa poznańskiego i kaliskiego wobec podwójnych elekcji lat 1697 i 1733. W: Wolna elekcja w dawnej..., s. 11; por. D. Statkiewicz: Franciszek Ludwik ksiązę Conti - kandydat „na sitę”, czyli ksiąze, który nie pragnąt korony. W: Wolna elekcja $w$ dawnej..., s. 91.

${ }^{51}$ VL V, s. $407-408$. 
„Oznajmienia Króla nowo obranego”, opisujący wypadki zaszłe w trakcie elekcji; jest w nim mowa o zgłoszeniu kandydatury najpierw Jakuba, a potem jego młodszych braci Aleksandra i Konstantego, jednak ci kandydaci nie uzyskali wystarczającego poparcia ${ }^{52}$, tym bardziej że młodsi Sobiescy w październiku 1696 r. wyjechali do Francji ${ }^{53}$. Jakub Sobieski, w trakcie elekcji przebywając w Częstochowie, poświęcił wiele pieniędzy, by zdobyć tron, jednak bezskutecznie ${ }^{54}$; w dużym stopniu kandydaturze jednego z Sobieskich szkodziła ich matka, upierając się pozostać w Warszawie w trakcie obrad sejmu konwokacyjnego. To zniechęciło szlachtę do rodziny zmarłego króla ${ }^{55}$. Młodych Sobieskich traktowano na równi z innymi kandydatami. Już bowiem Michał Korybut w swoich paktach konwentach potwierdził, że: „domus nostra ullam successionem et praetextum proximitatis ad Regnum sibi non praesumat" 56 oraz na sejmie w $1670 \mathrm{r}$. zapewnił o niedopuszczalności jakichkolwiek działań na rzecz osadzenia na tronie innego kandydata za życia koronowanego władcy, szczególnie w formie intryg, manipulacji politycznych i korupcji ${ }^{57}$.

Tymczasem, w paktach konwentach Augusta II znalazło się jednak wtrącone sformułowanie odnoszące się do jego sukcesorów królów polskich. Mianowicie, nabyte $\mathrm{w}$ trakcie panowania dla domu królewskiego dobra mają powrócić do Rzeczypospolitej, co zaprzysiągł pierwszy Sas w imieniu własnym „et pro Successoribus nostris Regibus Poloniae" ${ }^{\text {8 }}$. Należy dodać, że to zapewnienie zostało włączone do paktów konwentów po raz pierwszy ${ }^{59}$. Można zatem sobie wyobrazić, że Wettyn upatrywał nadziei na uzyskanie tronu Korony i Wielkiego Księstwa Litewskiego przez jego potomka, jeśli wcieli do Rzeczypospolitej ziemie nabyte w czasie swego panowania. Rzeczywiście, zabiegi takie August II Mocny czynił w pierwszym okresie swego regnum. Jednak ostatecznie drogą do uzyskania tronu Rzeczypospolitej przez Fryderyka Augusta miało stać się pozyskanie przychylności Polaków, którzy, o czym się przekonał, nigdy nie zrezygnują formalnie $\mathrm{z}$ wolnej elekcji, natomiast mają przywiązanie do raz wybranej familii królewskiej; casus Sobieskich był wyjątkiem od tej reguły ${ }^{60}$.

Jakie trudności rodził termin „wolna elekcja”, stało się zauważalne w związku z ekskluzją kandydatów cudzoziemskich na konwokacji w 1733 r.; stronnicy sascy uważali to za naruszenie zasady owej „wolnej elekcji”, co oznaczało, że pojęcie to odnosi się do biernego prawa wyborczego, ale także czynnego, czyli

\footnotetext{
${ }^{52}$ Ibidem, s. $459-460$.

${ }^{53}$ K. Jarochowski: Dzieje panowania Augusta II..., s. 62.

${ }^{54}$ E. Otwinowski: Pamiętniki. Biblioteka Kórnicka PAN 549, k. 3.

${ }^{55}$ E. Gąsior: Sejm konwokacyjny..., s. 185-195.

${ }^{56}$ VL V, s. 14, identyczny tekst w paktach konwentach Jana III, VL V, s. 139.

57 VL V, s. 28.

58 Volumina Legum. T. 6. Wyd. J. Ohryzko. Petersburg 1860, s. 15.

${ }^{59}$ Por. VL III, s. 362, VC IV, v. 1, s. 159, VL V, s. 14.

${ }^{60}$ J. Staszewski: August III Sas. Wrocław 2010, s. 124-127.
} 
prawa oddania głosu na dowolnego kandydata. Nałożoną na szlachtę przysięgę zaczęto opatrywać salwą o obowiązku zachowania dotychczasowego prawa o wolnej elekcji: „salvis omnibus constitutionibus de libera electione" ${ }^{61}$.

Sejm elekcyjny w 1733 r. rozpoczął się 25 sierpnia zwyczajowo od mszy św., w której trakcie z kazania biskupa chełmskiego Jana Feliksa Szaniawskiego wynikało, że elekcja króla jest pomyślna, gdy jest zjednoczona z „Elekcją Boską”. Wówczas bowiem „Bóg nam obiera królów”2 . Gloryfikacji wolnej elekcji podjął się również marszałek wcześniejszego sejmu konwokacyjnego Michał Józef Massalski, podkreślając, że w Rzeczypospolitej królem nie staje się kandydat jeszcze „W pieluchach”. Zgromadzeni poparli kandydaturę „Piasta” Stanisława Leszczyńskiego. Syn zmarłego króla Fryderyk August, choć dokonania jego ojca oficjalnie wychwalano, nie dysponował preferencjami do tronu. Tymczasem państwa ościenne (Rosja, Austria i Prusy), które jeszcze w 1732 r. zawarły porozumienie gwarantujące „wolność” elekcji w Rzeczypospolitej, a w rzeczywistości ingerujące $w$ jej przebieg za pomocą wojska i środków finansowych ${ }^{63}$. Ostatecznie więc, wbrew rezultatom legalnie zwołanej elekcji, królem został August III Wettyn; elekcja króla Rzeczypospolitej straciła całkowicie przymiot „wolnej”.

\section{Podsumowanie}

W polu zainteresowania badaczy znajdowała się wolna elekcja $\mathrm{w}$ aspekcie viritim; podkreślano dotychczas powszechność i równość w procedurze jej przeprowadzenia. Można przypuszczać, że kwestia prawa wybieralności nie była szerzej poruszana, gdyż przyjęto założenie, że królem Rzeczypospolitej mógł zostać wybrany dowolny kandydat, chyba że dokonano wyłączenia (ekskluzji) czy to cudzoziemców, czy to „Piasta”.

$\mathrm{Z}$ treści pierwszego postanowienia Artykułów henrykowskich literalnie należy wnosić, że elektowi zagwarantowano wybór któregoś z jego potomków (sukcesorów), skoro przewidziano sytuację, że ani Henryk Walezy, ani jego potomkowie, Królowie Polscy, nie będą zabiegać o koronowanie swego następcy za życia, nie będą również używać tytułu dziedzica. Ten przepis został następnie zmieniony poprzez usunięcie sformułowania o potomkach (sukcesorach)

${ }^{61}$ M. Wyszomirska: Z prosaskiej $i$ antystanisławowskiej publicystyki politycznej lat 1734-1736. (Wokól nieznanej twórczości Antoniego S. Dembowskiego). „Kwartalnik Historyczny" 2011, nr 3 - por. bibliografia, s. 436-437.

${ }^{62}$ Dyariusz Sejmu Walnego Electionis pod Interregnum de Anno MDCCXXXIII d. 25 Aug., http://pbc.biaman.pl/dlibra/docmetadata?id=82\&from=publication [dostęp: 23.03.2019].

${ }^{63}$ E. Cieślak: Z dziejów drugiej elekcji Stanisława Leszczyńskiego. Tajna przesyłka broni francuskiej do Gdańska w końcu 1733 r. „Śląski Kwartalnik »Sobótka«” 1982, nr 3-4, s. 421. 
królewskich na rzecz następców (następujących królach) w paktach konwentach Władysława IV Wazy. Powtarzano go następnie w kolejnych tego rodzaju aktach. Starania czynione przez Zygmunta III w kierunku cesji tronu na rzecz Habsburgów a w późniejszym czasie elekcji vivente rege królewicza Władysława, czyli jednoznaczne próby złamania postanowienia Artykułów henrykowskich, szlachta traktowała jako naruszenie prawa. Przeciwdziałała temu, wprowadzając w paktach konwentach reguły elekcyjności tronu w zmienionej formule. Zabieg ten należy traktować jako świadomy, w celu uniknięcia jakichkolwiek interpretacji na korzyść domu królewskiego; doszło do reinterpretacji łacińskiego określenia „sukcesor”. Szlachta chciała sobie zagwarantować swobodny wybór elekta, niezależnie od pozostających przy życiu następców prawnych zmarłego monarchy.

\section{Bibliografia}

\section{Źródla}

Akta grodzkie i ziemskie. T. 24: Lauda sejmikowe halickie 1575-1695. Wyd. A. Prochaska. Lwów 1931.

Dyariusz Sejmu Walnego Electionis pod Interregnum de Anno MDCCXXXIII $d .25$ Aug., http://pbc.biaman.pl/dlibra/docmetadata?id=82\&from=publication [dostęp: 23.03.2019].

Dyjaryjusze sejmowe 1587. Sejmy konwokacyjny i elekcyjny. Wyd. A. Sokołowski. Kraków 1887, Scriptores Rerum Polonicarum, T. 21.

Otwinowski E.: Pamiętniki. Biblioteka Kórnicka PAN 549.

Senator Anonim: Traktat de interregno z r. 1587. W: Sześć broszur politycznych z XVI i początku XVII stulecia. Wyd. B. Ulanowski. Kraków 1921, https://bibliotekacyfrowa.pl/dlibra/publication/39297/edition/40476/content [dostęp: 14.02.2019].

Volumina Constitutionum. T. 1: 1493-1549, Vol. 2: 1527-1549. Do druku przygotowali W. Uruszczak, S. Grodziski, I. Dwornicka. Warszawa 2000.

Volumina Constitutionum. T. 2: 1550-1609, Vol. 1: 1550-1585. Do druku przygotowali S. Grodziski, I. Dwornicka, W. Uruszczak. Warszawa 2005.

Volumina Constitutionum. T. 2: 1550-1609, Vol. 2: 1587-1609. Do druku przygotował S. Grodziski, przedmowa W. Uruszczak. Warszawa 2008.

Volumina Constitutionum. T. 4: 1641-1668, Vol. 1: 1641-1658. Do druku przygotowa-

li S. Grodziski, M. Kwiecień, K. Fokt, przedmowa W. Uruszczak. Warszawa 2015.

Volumina Legum. T. 3. Wyd. J. Ohryzko. Petersburg 1859.

Volumina Legum. T. 5. Wyd. J. Ohryzko. Petersburg 1860.

Volumina Legum. T. 6. Wyd. J. Ohryzko. Petersburg 1860. 
Volumina Legum. T. 9. Kraków 1889.

Zbiór pamiętników do dziejów polskich. T. 3. Wyd. W.S. de Plater-Broel. Warszawa 1858.

\section{Opracowania}

Cieślak E.: Z dziejów drugiej elekcji Stanisława Leszczyńskiego. Tajna przesyłka broni francuskiej do Gdańska w końcu 1733 r. „Śląski Kwartalnik »Sobótka«” 1982, nr 3-4.

Dzięgielewski J.: Sejmy elekcyjne, elektorzy, elekcje 1573-1674. Pułtusk 2003.

Frydrych-Depka A.: „Prawnoczłowiecze” spojrzenie na czynne prawo wyborcze. „Studia Wyborcze” 2016, T. 21.

Gąsior E.: Sejm konwokacyjny po śmierci Jana III Sobieskiego. Warszawa 2017.

Glabisz G.: Sejmik województwa poznańskiego i kaliskiego wobec podwójnych elekcji lat 1697 i 1733. W: Wolna elekcja $w$ dawnej Rzeczypospolitej. Procedura - przebieg - publicystyka. Red. A. Ziober. Wrocław 2014.

Jarochowski K.: Dzieje panowania Augusta II od śmierci Jana III do chwili wstapienia Karola XII na ziemię polska. Poznań 1856.

Lewandowska-Malec I.: Prawo do elekcji króla Rzeczypospolitej w latach 15871648. W: Historia testis temporum, lux veritatis, vita memoriae, nuntia vetustatis: księga jubileuszowa dedykowana Profesorowi Włodzimierzowi Kaczorowskiemu. Red. E. Kozerska, M. Maciejewski, P. Stec. Opole 2015.

Makiłła D.: Artykuły henrykowskie (1573-1576). Geneza - obowiazywanie - stosowanie. Studium historyczno-prawne. Warszawa 2012.

Piechowiak M.: Prawo a wolność. W: Prawa czlowieka - prawa rodziny. 30 lat Poznańskiego Zakładu Instytutu Nauk Prawnych PAN. Red. R. Hliwa, A.N. Schulz. Poznań 2003.

Staszewski J.: August III Sas. Wrocław 2010.

Statkiewicz D.: Franciszek Ludwik książe Conti - kandydat „na siłę”, czyli ksiązęe, który nie pragną korony. W: Wolna elekcja $w$ dawnej Rzeczpospolitej. Procedura — przebieg - publicystyka. Red. A. Ziober. Wrocaw 2014.

Szabelski A.: Projekty elekcji vivente rege $w$ Rzeczypospolitej, a wegierskie doświadczenia z elekcja vivente rege. W: Wolna elekcja $w$ dawnej Rzeczypospolitej. Procedura — przebieg — publicystyka. Red. A. Ziober. Wrocław 2014.

Śmigiel K.: Prymasi interreksi. „Studia Gnesnensia” 2011, T. 25.

Ujma M.: Sejmik lubelski 1572-1696. Warszawa 2003.

Uruszczak W.: Historia państwa i prawa polskiego. T. 1: (966-1795). Warszawa 2013.

Wokót wolnych elekcji w państwie polsko-litewskim XVI-XVIII wieku. O znaczeniu idei wyboru - między prawami a obowiązami. Red. M. Markiewicz, D. Rolnik, F. Wolański. Katowice 2016.

Woliński J.: Epilog elekcji 1674 r. Kraków 1952.

Wyszomirska M.: Z prosaskiej $i$ antystanisławowskiej publicystyki politycznej lat 1734-1736. (Wokól nieznanej twórczości Antoniego S. Dembowskiego). „Kwartalnik Historyczny" 2011. 


\section{Źródla internetowe}

https://pl.wikipedia.org/wiki/Wolna_elekcja

http://www.tomaszewska.com.pl/elekcja.pdf

https://sjp.pl/wolny

http://www.wilanow-palac.pl/elekcja_michala_korybuta_wisniowieckiego.html

http://pbc.biaman.pl/dlibra/docmetadata?id=82\&from=publication

Izabela Lewandowska-Malec

\section{Freie Wahl des Königs der Republik beider Nationen}

Schlüsselwörter: Republik beider Nationen, Articuli Henriciani, Pacta conventa, freie Wahl, passives Wahlrecht

Zusammenfassung: Wahlrechte sind aktiv oder passiv; sie bedeuten das Recht zu wählen und gewählt zu werden. In der Republik beider Nationen war das Recht auf „freie Wahl“ des Königs eines der grundlegenden Prinzipien im politischen System. Verstanden wurde es als das Recht auf die Wahl viritim, was bedeutete, dass jeder Adlige seine Stimme abgeben konnte. Dies galt als der größte Erfolg der Adelsnation in der Republik. Das passive Wahlrecht war kein Gegenstand weiterer Überlegungen in der damaligen Publizistik und im öffentlichen Leben. Dieser Aspekt muss unter Berücksichtigung der Bestimmungen der Articuli Henriciani und Pacta conventa erforscht werden.

Izabela Lewandowska-Malec

\section{The free election of the king of the Polish-Lithuanian Commonwealth}

Keywords: Polish-Lithuanian Commonwealth, Henrician Articles, pacta conventa, free election, passive voting right

Summary: The right to vote is either active or passive; it means the right to vote and to be elected. During the period of the Polish-Lithuanian Commonwealth, one of the fundamental principles of the political system was the right to "free election" of the king. It was understood as electio viritim, i.e. casting a vote by each nobleman. This was considered to be the greatest success of the noble nation in the Republic of Poland. In the passive aspect, electoral law was not a subject of broader considerations in contemporary journalism and public life. This issue requires scientific research, taking into account the provisions of Henrician Articles and pacta conventa. 